\title{
Balance performance and fear of falling in older patients with diabetics: a comparative study with non-diabetic elderly
}

\author{
Diyabetli yaşlılarda denge ve düşme korkusu: Diyabetli olmayan yaşlılarla karşılaştırmalı bir çalışma
}

\author{
Berna Tander, ${ }^{1}$ Ayşegül Atmaca, ${ }^{2}$ Yasemin Ulus,, Çiğdem Tura, ${ }^{2}$ Yeşim Akyol, ${ }^{1}$ Ömer Kuru ${ }^{1}$ \\ 1Department of Physical Medicine and Rehabilitation, Medical Faculty of Ondokuz Mayıs University, Samsun, Turkey \\ ${ }^{2}$ Department of Endocrinology and Metabolism, Medical Faculty of Ondokuz Mayıs University, Samsun, Turkey
}

Received / Geliş tarihi: September 2015 Accepted / Kabul tarihi: November 2015

\begin{abstract}
Objectives: This study aims to evaluate balance performance and fear of falling (FOF) in older people with and without diabetes mellitus (DM) and the parameters affecting balance and FOF in older patients with DM.

Patients and methods: Between 2013 June - 2014 April, a total of 100 patients with DM (37 males, 63 females; mean age $66.8 \pm 4.3$ years; range 60 to 83 years) and 101 non-diabetic elderly controls ( 35 males, 66 females; mean age $68.0 \pm 4.3$ years; range 64 to 81 years) were enrolled in this study. Fear of falling (Falls Efficacy Scale-International (FES-I)), neuropathic pain [Leeds Assessment of Neuropathic Symptoms-Signs (LANSS)], mobility [Timed Up and Go test (TUG)], balance [Berg Balance Scale (BBS)], One-Legged Stance test (OLST), disability status [Modified Barthel Index (MBI)], depression [Beck Depression Inventory (BDI)] and anxiety [Beck Anxiety Inventory (BAI)] were assessed.

Results: Timed Up and Go test, BDI, BAI, and FES-I scores were significantly higher; BBS, OLST, and MBI scores were significantly lower in patients. There were significant effects of neuropathic pain, hypertension and cardiovascular disease on BBS and FES-I in diabetic patients. One-Legged Stance test, TUG, and FES-I were associated with BBS in diabetic patients. Falls Efficacy Scale-International was significantly correlated with $\mathrm{HbA1c}, \mathrm{MBI}$ and BBS in patients.
\end{abstract}

Conclusion: Older people with DM have increased FOF and balance problems. Uncontrolled DM, cardiovascular problems and neuropathic pain have negative impact on balance and FOF. Physiatrist should also take part in the follow-up of older diabetic patients.

Keywords: Ageing; balance; diabetes mellitus; emotional status; fear of falling.

$\ddot{O Z Z}$

Amaç: Bu çalışmada diyabetli olan ve olmayan yaşlılarda denge ve düşme korkusu (DK) ve yaşlı diyabetli hastalarda denge ve DK'ye etki eden parametreler değerlendirildi.

Hastalar ve yöntemler: Haziran 2013 - Nisan 2014 tarihleri arasında, toplam 100 diyabetli hasta (37 erkek, 63 kadın; ort. yaş $66.8 \pm 4.3$ yıl; dağılım 60-83 yıl) ve 101 diyabetli olmayan yaşlı kontrol (35 erkek, 66 kadın; ort. yaş 68.0 44.3 yıl; dağılım 64-81 yıl) çalışmaya alındı. Düşme korkusu [Uluslararası Düşme Etkinlik Skalası (UDES)], nöropatik ağrı [Leeds Nöropatik Semptomlar-Bulgular Değerlendirme (LANSS)] mobilite [Kalk ve Yürü Testi (KYT)], denge [Berg Denge Skalası (BDS)], Tek Bacak Üzerinde Durma Testi (TBÜDT), özürlülük düzeyi [Modifiye Barthel İndeksi (MBİ)], depresyon [Beck Depresyon Ölçeği (BDÖ)] ve anksiyete [Beck Anksiyete Ölçeği (BAÖ)] ile değerlendirildi. Bulgular: Hastalarda KYT, BDÖ, BAÖ ve UDES skorları anlamlı olarak yüksek, BDS, TBÜDT ve MBİ skorları anlamlı olarak düşüktü. Diyabetik hastalarda nöropatik ağrının, hipertansiyonun ve kardiyovasküler hastalığın BDS ve UDES skorları üzerinde önemli etkisi vardı. Diyabetik hastalarda TBÜDT, KYT ve UDES, BDS ile anlamlı olarak ilişkiliydi. Hastalarda UDES skoru HbA1c, MBİ ve BDS ile anlamlı olarak ilișkiliydi.

Sonuç: Yaşlı diyabetliler artmış düşme korkusu ve denge sorunlarına sahiptir. Kontrolsüz diyabet, kardiyovasküler sorunlar ve nöropatik ağrının denge ve DK üzerine olumsuz etkisi bulunmaktadır. Yaşlı diyabetik hastaların izleminde fiziyatrist de rol almalıdır.

Anahtar sözcükler: Yaşlanma; denge; diyabetes mellitus; emosyonel durum; düşme korkusu.

Corresponding author / İletişim adresi: Berna Tander, MD. Ondokuz Mayıs Üniversitesi Tıp Fakültesi Fiziksel Tıp ve Rehabilitasyon Anabilim Dalı, 55139 Atakum, Samsun, Turkey. e-mail / e-posta: bernatander@gmail.com 
Balance is a complex phenomenon which involves the ability to feel the position of the body relative to your surroundings and utilize motor responses to control body movement. Balance problems may cause falls especially in older people. ${ }^{[1]}$ Many factors may be associated with falls such as age related changes in postural stability, person's ability to control balance and impaired mobility. ${ }^{[1,2]}$ Reduced self-efficacy related to falls avoidance during daily activities is defined as fear of falling. ${ }^{[3]}$ Fear of falling (FOF) is perceived as a common problem in older people has been associated with restricted activity, decreased physical function and lower quality of life. ${ }^{[3,4]}$

Diabetes mellitus (DM) is a systemic chronic disease which leads to peripheral and central neuropathy, retinopathy, poor glycemic control and impairments in locomotor function. ${ }^{[5,6]}$ Apart from these impairments, diabetes medication and/or polypharmacy may cause damage to the balance maintenance systems, besides being a strong predictor of self-referred functional limitations, worsening performance in lower limb functions and falls. ${ }^{[7,8]}$ The prevalence of diabetic complications significantly increases along with the duration of the disease, age and poor patient glycemic control..$^{[9,10]}$ Therefore it is not surprising that patients with DM may have balance control problems and FOF. In previous studies, comparing older adults with or without a FOF and/or low balance confidence, associations between FOF and balance performance have been found.

The literature suggests that poor balance and increased FOF may be warning signs for falls in older patients with DM. ${ }^{[7]}$ However, there are not any detailed studies evaluating the factors associated with diminished balance and increased FOF in diabetic patients. ${ }^{[11-13]}$ This study has been designed as a crosssectional study which aimed to discover the differences of balance performance and FOF in older patients with DM and without DM. Furthermore; diabetes related complications, comorbidities, duration of diabetes, laboratory findings, psychological factors such as depression and anxiety, and the ability to maintain daily activities were evaluated as confounding parameters for balance and FOF in older diabetic patients.

\section{PATIENTS AND METHODS}

Between 2013 June - 2014 April, a total of 100 patients with DM (37 males, 63 females; mean age $66.8 \pm 4.3$ years; range 60 to 83 years) and 101 healthy control patients (35 males, 66 females; mean age
$68.0 \pm 4.3$ years; range 64 to 81 years) were enrolled in this study. The study was conducted according to principals of Declaration of Helsinki, 2008, approved by Ondokuz Mayıs University School of Medicine Medical Ethics Committee (302) and all subjects gave written informed consent. Patients with either a known diagnosis of type $2 \mathrm{DM}$ or fasting plasma glucose $\geq 126 \mathrm{mg} / \mathrm{dL}$ according to the American Diabetes Association criteria were included in the study. ${ }^{[14]}$ All participants were questioned about age, sex, highest level of education, employment status, use of assistive devices for ambulation (yes/no), history of chronic diseases and current medications. Height, weight and body mass index (BMI) $\left(\mathrm{kg} / \mathrm{m}^{2}\right)$ were measured according to international standards. All subjects were also asked about the number of falls in the last 12 months. All subjects were asked if they were afraid of falling. In addition, each individual rated her/his self-perception of overall well-being on a Likert-type scale as excellent, very good, good, fair or poor. In diabetic patients, data about clinical features, disease duration, comorbidities, and the type of treatment for DM (insulin, oral, medications and/or lifestyle modification) and recent ( $\leq 3$ months) Hemoglobin A1C (HbAlc) were recorded from the participant's medical records.

Individuals were excluded if they had concomitant foot ulcers, orthopedic or surgical problems influencing gait, amputation of lower extremities, a non-diabetic neuropathy (as a result of Charcot-Marie-Tooth disease, alcohol or thyroid dysfunction), unstable medical conditions, evidence of vestibular dysfunction, plantar skin sore or joint replacement within the previous year. Symptomatic postural hypotension, neurological pathology influencing gait or an ability to walk $500 \mathrm{~m}$ without a walking aid were also reasons for exclusion from the study. Participants diagnosed with severe cognitive impairment, dementia or Alzheimer's disease by a neurologist and/or a psychiatrist, were also excluded. Participants who regularly exercised or participating in any physical activity program, were included.

The Leeds Assessment of Neuropathic Symptoms and Signs (LANSS) pain scale is an easily applied clinical instrument developed and validated to recognize neuropathic pain and set it apart from nociceptive pain. A LANSS score of 12 and above was considered to show the presence of neuropathic pain. The reliability and validity of the Turkish version of LANSS pain scale was performed by Yucel et al. ${ }^{[15]}$

Static balance of the subjects was evaluated with a One-Legged Stance Test (OLST) with eyes open. 
Test was performed for 30 seconds. Three trials were allowed and the best result was used. ${ }^{[16]}$

The Berg Balance Scale (BBS) was originally developed for the assessment of postural control, and is widely used in many fields of rehabilitation. The reliability and validity of the Turkish form of BBS was performed by Sahin et al. ${ }^{[17]}$

The Timed Up and Go test (TUG) was used to evaluate mobility. The time required to complete the task is measured in seconds. It has been suggested that elders with longer TUG times are more likely to fall than those with shorter times. ${ }^{[18]}$

The Turkish version of Modified Barthel Index (MBI) was used to evaluate the level of disability with respect to activities of daily living. ${ }^{[19]}$ The MBI consists of 10 activities, scored with respect to physical assistance required.

Falls Efficacy Scale-International (FES-I) is a selfreported questionnaire that assesses level of concern about falls during daily activities. The reliability and validity of the Turkish version of FES-I was performed by Ulus et al. ${ }^{[20]}$

Beck Depression Inventory (BDI) is a self-reported questionnaire that assesses depressive symptoms during the week prior to the interview. The reliability and validity of Turkish version of BDI was performed by Hisli. ${ }^{[2]]}$

Beck Anxiety Inventory (BAI) is a self-reported questionnaire that assesses anxiety symptoms during the week prior to the interview. The reliability and validity of Turkish version of BDI was performed by Ulusoy et al. ${ }^{[22]}$

\section{Statistical analysis}

Statistical analyses were performed using SPSS for Windows version 16.0 software (SPSS Inc., Chicago, IL, USA). The Kolmogorov Smirnov test was used to analyze normal distribution assumption of the quantitative outcomes and all data were not normally distributed. Descriptive data were presented as mean \pm standard deviation (SD) or median (minimummaximum). The socio-demographical characteristics of the groups were evaluated by Chi-square test. To compare the groups Mann-Whitney U test was used. Correlations were investigated using Spearman correlation analysis. In DM patients, univariate analysis of variance (ANOVA) was used to assess the effects of gender, presence of neuropathic pain, presence of diabetic complications and comorbidities on BBS and FES-I. Multivariate linear regression analysis was performed in order to analyze the relationship between BBS and FES-I and other clinical assessments in patients with DM. Sample size estimation was performed using PASS 2008 software. In order to have statistical power of 0.90 , and $p<0.05$, it was calculated that 89 subjects in each group were required to detect the differences in OLST scores between the groups. We planned to have a total of 200 study participants in order to increase the trial strength. $P$ values less than 0.05 were considered statistically significant.

\section{RESULTS}

The mean duration of the disease was $11.4 \pm 8.0$ (range 1-36) years. Patients' characteristics by diabetes status are summarized in Table 1. Sociodemographic characteristics and comorbidities of the patients and

Table 1. Sociodemographic characteristics and clinical features of the patients $(n=100)$

\begin{tabular}{|c|c|c|c|c|c|}
\hline Characteristics & $\mathrm{n}$ & $\%$ & Mean \pm SD & Median & Min.-Max. \\
\hline Age (years) & & & $66.83 \pm 4.31$ & 65 & $60-83$ \\
\hline Duration of diabetes (years) & & & $11.38 \pm 7.96$ & 10 & $1-36$ \\
\hline $\mathrm{HbAlc}(\mathrm{mmol} / \mathrm{mol})$ & & & $8.55 \pm 1.68$ & 8.5 & $5.9-14.8$ \\
\hline LANSS score & & & $11.26 \pm 9.08$ & 11 & $0-30$ \\
\hline$<12$ & & 52 & & & \\
\hline$>12$ & & 48 & & & \\
\hline Peripheral neuropathy & 18 & 18 & & & \\
\hline Retinopathy & 26 & 26 & & & \\
\hline Overt nephropathy & 11 & 11 & & & \\
\hline Microalbuminuria & 15 & 15 & & & \\
\hline Peripheral artery disease & 7 & 7 & & & \\
\hline Use of gabapentin + pregabalin & 11 & 11 & & & \\
\hline Use of insulin & 64 & 64 & & & \\
\hline Use of oral hypoglycemic agent & 35 & 35 & & & \\
\hline Hypoglycemia & 56 & 56 & & & \\
\hline
\end{tabular}


control subjects and their comparison are shown in Table 2.

No significant differences were found regarding age, gender, level of education, occupation, presence of hypertension, use of walking aids and present health status between patients and controls $(p>0.05)$ (Table 2). In contrast, marital status, BMI, presence of hyperlipidemia, cardiovascular disease, fear of falling and number of falls in the last year were significantly different between the two groups $(\mathrm{p}<0.05)$. Moreover, the TUG, BDI, BAI, and FES-I scores were also significantly higher in the patient group than in the control group $(\mathrm{p}<0.001)$ (Table 2$)$. In addition the scores of BBS, OLST, and MBI were also lower in patients than the controls $(\mathrm{p}<0.001)$ (Table 2).

In the patient group; the mean FES-I and BBS scores were $35.2 \pm 11.5$ (range 16-70) and 42.7 \pm 7.4 (range 20-55) in women and 24.6 \pm 10.2 (range 16-52) and 49.7 \pm 7.8 (range 21-59) in men, respectively. The FES-I scores were significantly higher, and BBS scores were significantly lower in women $(\mathrm{p}<0.001)$. Furthermore,

Table 2. Comparison of sociodemographical and clinical characteristics of the patient and control groups

\begin{tabular}{|c|c|c|c|c|c|c|c|c|c|c|c|}
\hline & \multicolumn{5}{|c|}{ Patients $(\mathrm{n}=100)$} & \multicolumn{5}{|c|}{ Controls $(\mathrm{n}=101)$} & \multirow[b]{2}{*}{$p$} \\
\hline & $\mathrm{n}$ & $\%$ & Mean \pm SD & Median & Min.-Max. & $\mathrm{n}$ & $\%$ & Mean \pm SD & Median & Min.-Max. & \\
\hline Gender & & & & & & & & & & & 0.729 \\
\hline Female & 63 & 63 & & & & 66 & 65.3 & & & & \\
\hline Male & 37 & 37 & & & & 35 & 34.7 & & & & \\
\hline Education & & & & & & & & & & & 0.649 \\
\hline Primary school & 80 & 80 & & & & 82 & 81.2 & & & & \\
\hline Secondary school & 12 & 12 & & & & 14 & 13.8 & & & & \\
\hline University/college & 8 & 8 & & & & 5 & 4.9 & & & & \\
\hline Occupation & & & & & & & & & & & 0.256 \\
\hline House-work & 50 & 50 & & & & 56 & 55.5 & & & & \\
\hline Retired & 36 & 36 & & & & 38 & 37.6 & & & & \\
\hline Others & 14 & 14 & & & & 7 & 6.9 & & & & \\
\hline Marital status & & & & & & & & & & & 0.018 \\
\hline Married & 75 & 75 & & & & 91 & 90.1 & & & & \\
\hline Single & 2 & 2 & & & & 1 & 1.0 & & & & \\
\hline Widowed & 23 & 23 & & & & 9 & 8.9 & & & & \\
\hline Hypertension & & & & & & & & & & & 0.205 \\
\hline No & 32 & 32 & & & & 41 & 40.6 & & & & \\
\hline Yes & 68 & 68 & & & & 60 & 59.4 & & & & \\
\hline Dyslipidemia & & & & & & & & & & & 0.001 \\
\hline No & 45 & 45 & & & & 85 & 84.2 & & & & \\
\hline Yes & 55 & 55 & & & & 16 & 15.8 & & & & \\
\hline Any cardiovascular disease & & & & & & & & & & & 0.001 \\
\hline No & 78 & 78 & & & & 95 & 95.0 & & & & \\
\hline Yes & 22 & 22 & & & & 6 & 6.0 & & & & \\
\hline Use of walking aids & & & & & & & & & & & 0.060 \\
\hline Without aids & 94 & 94 & & & & 87 & 86.1 & & & & \\
\hline Cane & 6 & 6 & & & & 14 & 13.9 & & & & \\
\hline Fear of falling & & & & & & & & & & & 0.023 \\
\hline No & 35 & 35 & & & & 46 & 45.5 & & & & \\
\hline Yes & 65 & 65 & & & & 55 & 33.5 & & & & \\
\hline Age (years) & & & $66.8 \pm 4.3$ & 65 & $60-83$ & & & $68.0 \pm 4.3$ & 65 & $64.0-81$ & 0.098 \\
\hline Body mass index $\left(\mathrm{kg} / \mathrm{m}^{2}\right)$ & & & $31.5 \pm 6.4$ & 31.2 & $5.0-48$ & & & $29.7 \pm 5.0$ & 29 & $20.7-46.6$ & 0.007 \\
\hline Present health status & & & $3.6 \pm 0.1$ & 4.0 & $1.0-5.0$ & & & $3.4 \pm 0.6$ & 3.0 & $2.0-5.0$ & 0.104 \\
\hline Number of falls in the & & & & & & & & & & & \\
\hline last 12 months & & & $1.1 \pm 1.9$ & 0.0 & $0-100$ & & & $0.4 \pm 0.8$ & 0.0 & $0-4.0$ & 0.001 \\
\hline BBS score & & & $45.3 \pm 8.2$ & 46 & $20-59$ & & & $49.0 \pm 6.7$ & 50 & $21-56$ & 0.001 \\
\hline TUG score (seconds) & & & $12.7 \pm 3.3$ & 12 & $6.0-25$ & & & $7.5 \pm 3.4$ & 7.0 & $3.0-36$ & 0.001 \\
\hline OLST (seconds) & & & $11.3 \pm 10.2$ & 7.0 & $1.0-30$ & & & $17.9 \pm 9.4$ & 17 & $2.0-30$ & 0.001 \\
\hline MBI score & & & $94.0 \pm 9.2$ & 100 & $55-100$ & & & $98.4 \pm 3.3$ & 100 & $80-100$ & 0.001 \\
\hline FES-I score & & & $31.3 \pm 12.2$ & 30 & $16-70$ & & & $21.1 \pm 7.3$ & 16 & $16-49$ & 0.001 \\
\hline BDI score & & & $17.1 \pm 11.6$ & 14 & $0-52$ & & & $9.5 \pm 7.7$ & 8.0 & $0-36$ & 0.001 \\
\hline BAI score & & & $19.3 \pm 14.3$ & 15 & $0-57$ & & & $8.4 \pm 9.5$ & 4.0 & $0-36$ & 0.001 \\
\hline
\end{tabular}

SD: Standard deviation; Min.: Minimum; Max.: Maximum; BBB: Berg Balance Scale; TUG: The Timed Up and Go Test; OLST: One-Legged Stance Test; MBI: Modified Barthel Index; FES-I: Falls Efficacy Scale-International; BDI: Beck Depression Inventory; BAI: Beck Anxiety Inventory; p value is significant when $<0.05$. 
gender was found to be effective on FES-I scores $(\mathrm{p}<0.001)$ and BBS scores $(\mathrm{p}=0.002)$ using univariate ANOVA.

The univariate ANOVA also showed significant effects of the presence of neuropathic pain $(p<0.001)$, the presence of hypertension $(p=0.041)$, and the presence of any cardiovascular disease $(\mathrm{p}=0.001)$ on BBS scores. Likewise, the presence of neuropathic pain $(\mathrm{p}<0.001)$, presence of hypertension $(\mathrm{p}=0.032)$, and presence of any cardiovascular disease $(\mathrm{p}=0.001)$ were found to be effective on FES-I scores by univariate ANOVA. No significant effects of diabetes medications or the presence of diabetic complications (peripheral neuropathy, visual impairment, nephropathy, microalbuminuria, and peripheral arterial disease) on FES-I and BBS scores were found by univariate ANOVA ( $p>0.05)$.
Spearman's correlation coefficient results for DM patients (Table 3) showed that BBS scores had a strong significant negative correlation between BMI, duration of disease, HbAlc, LANSS, TUG, FES-I, $\mathrm{BDI}$, and BAI scores, positive correlation with MBI and OLST scores $(\mathrm{p}<0.001)$ (Table 3). On the other hand, FES-I score was positively correlated with BMI, duration of disease, HbAlc, TUG, LANSS, BAI, and BDI scores and negatively correlated with OLST, BBS and MBI scores.

In patients with $\mathrm{DM}$, multiple regression analyses (Table 4) revealed that OLST, TUG, and FES-I scores were associated with BBS. On the other hand, FES-I was significantly correlated with $\mathrm{HbAlc}, \mathrm{MBI}$, and BBS scores in diabetic patients (Table 4). Other variables were not associated with BBS and FES-I scores ( $>0.005)$ (Table 4).

Table 3. Spearman correlation coefficient of the variables

\begin{tabular}{|c|c|c|c|c|c|c|c|c|c|c|c|c|}
\hline \multicolumn{13}{|l|}{ Age } \\
\hline $\mathrm{r}$ & 1 & -0.047 & 0.045 & 0.057 & 0.057 & -0.193 & -0.185 & 0.141 & 0.132 & -0.223 & 0.080 & 0.113 \\
\hline $\mathrm{p}$ & & 0.639 & 0.657 & 0.574 & 0.571 & 0.055 & 0.066 & 0.161 & 0.192 & 0.026 & 0.428 & 0.263 \\
\hline \multicolumn{13}{|l|}{ BMI } \\
\hline$r$ & & 1 & -0.134 & -0.086 & 0.134 & -0.240 & -0.164 & 0.044 & 0.265 & -0.112 & 0.107 & 0.231 \\
\hline $\mathrm{p}$ & & & 0.184 & 0.395 & 0.066 & 0.016 & 0.103 & 0.667 & 0.008 & 0.268 & 0.288 & 0.021 \\
\hline \multicolumn{13}{|c|}{ Duration of disease } \\
\hline $\mathrm{r}$ & & & 1 & 0.322 & 0.354 & -0.308 & -0.262 & 0254 & 0.295 & -0.195 & 0.256 & 0.166 \\
\hline $\mathrm{p}$ & & & & 0.001 & $<0.001$ & 0.002 & 0.009 & 0.011 & 0.003 & 0.052 & 0.010 & 0.099 \\
\hline \multicolumn{13}{|c|}{ HbAlc } \\
\hline $\mathrm{r}$ & & & & 1 & 0.263 & -0.208 & -0.212 & 0.201 & 0.280 & -0.305 & 0.162 & 0.091 \\
\hline $\mathrm{p}$ & & & & & 0.008 & 0.038 & 0.034 & 0.044 & 0.006 & 0.002 & 0.106 & 0.365 \\
\hline \multicolumn{13}{|c|}{ LANSS } \\
\hline $\mathrm{r}$ & & & & & 1 & -0.470 & -0.307 & 0.305 & 0.514 & -0.476 & 0.517 & 0.591 \\
\hline $\mathrm{p}$ & & & & & & $<0.001$ & 0.002 & 0.002 & $<0.001$ & $<0.001$ & $<0.001$ & $<0.001$ \\
\hline \multicolumn{13}{|l|}{ BBS } \\
\hline $\mathrm{r}$ & & & & & & 1 & 0.676 & -0.593 & -0.727 & 0.492 & -0.501 & -0.558 \\
\hline $\mathrm{p}$ & & & & & & & $<0.001$ & $<0.001$ & $<0.001$ & $<0.001$ & $<0.001$ & $<0.001$ \\
\hline \multicolumn{13}{|c|}{ OLST } \\
\hline $\mathrm{r}$ & & & & & & & 1 & -0.428 & -0.555 & 0.351 & 0.261 & -0.508 \\
\hline $\mathrm{p}$ & & & & & & & & $<0.001$ & $<0.001$ & $<0.001$ & 0.009 & $<0.001$ \\
\hline \multicolumn{13}{|c|}{ TUG } \\
\hline $\mathrm{r}$ & & & & & & & & 1 & 0.524 & -0.311 & 0.261 & 0.271 \\
\hline $\mathrm{p}$ & & & & & & & & & $<0.001$ & 0.002 & 0.009 & 0.006 \\
\hline \multicolumn{13}{|c|}{ FES-I } \\
\hline $\mathrm{r}$ & & & & & & & & & 1 & -0.508 & 0.650 & 0.697 \\
\hline $\mathrm{p}$ & & & & & & & & & & $<0.001$ & $<0.001$ & $<0.001$ \\
\hline \multicolumn{13}{|l|}{ MBI } \\
\hline $\mathrm{r}$ & & & & & & & & & & 1 & -0.405 & 0.799 \\
\hline $\mathrm{p}$ & & & & & & & & & & & $<0.001$ & $<0.001$ \\
\hline \multicolumn{13}{|l|}{ BDI } \\
\hline$r$ & & & & & & & & & & & 1 & 0.799 \\
\hline $\mathrm{p}$ & & & & & & & & & & & & $<0.001$ \\
\hline \multicolumn{13}{|l|}{ BAI } \\
\hline $\mathrm{r}$ & & & & & & & & & & & & 1 \\
\hline $\mathrm{p}$ & & & & & & & & & & & & \\
\hline
\end{tabular}

p value is significant when $<0.05$; r: Spearman's correlation coefficient; BMI: Body mass index; HAblc: Hemoglobin (Hb) Alc; LANSS: Leeds Assessment of Neuropathic Symptoms and Signs; BBS: Berg Balance Scale; OLST: One-Legged Stance Test; TUG: The Timed Up and Go Test; FES-I: Falls Efficacy Scale-International; MBI: Modified Barthel Index; BDI: Beck Depression Inventory; BAI: Beck Anxiety Inventory. 
Table 4. Multiple regression analysis with Berg Balance Scale and Falls Efficacy Scale-International as dependent variables and age, body mass index, disease duration and clinical assessments as independent variables in patients with diabetes mellitus

\begin{tabular}{|c|c|c|c|c|c|c|}
\hline & \multicolumn{3}{|c|}{ BBS } & \multicolumn{3}{|c|}{ FES-I } \\
\hline & $\beta$ & $\mathrm{t}$ & $\mathrm{p}$ & $\beta$ & $\mathrm{t}$ & $\mathrm{p}$ \\
\hline Age & $-0,099$ & 0.101 & 0.328 & 0.054 & 0.264 & 0.792 \\
\hline Body mass index & -0.023 & -0.344 & 0.731 & 0.274 & 1.318 & 0.191 \\
\hline Disease duration & -0.042 & -0.794 & 0.430 & -0.028 & -0.024 & 0.981 \\
\hline HbAlc & 0.538 & 2.120 & 0.037 & 0.350 & 2.245 & 0.026 \\
\hline Number of falls & -0.076 & -1.230 & 0.222 & 0.082 & 1.273 & 0.207 \\
\hline Fear of falling & 0.100 & 0.153 & 0.879 & 1.671 & 1.764 & 0.082 \\
\hline Leeds Assessment of Neuropathic Symptoms and Signs & -0.051 & -0.893 & 0.374 & -0.002 & -0.031 & 0.975 \\
\hline One-legged Stance Test & 0.254 & 5.105 & $<0.001$ & -0.125 & -2.515 & 0.013 \\
\hline The Timed Up and Go Test & -0.382 & -2.668 & 0.009 & 0.147 & 1.090 & 0.277 \\
\hline Modified Barthel Index & 0.206 & 3.483 & 0.001 & -0.216 & -2.757 & 0.006 \\
\hline Berg Balance Scale & - & - & - & -0.509 & -3.245 & 0.002 \\
\hline Falls Efficacy Scale-International & -0.190 & -3.466 & 0.001 & - & - & - \\
\hline Beck Depression Inventory & 0.099 & 1.716 & 0.090 & 0.075 & 0.678 & 0.500 \\
\hline Beck Anxiety Inventory & -0.058 & -1.031 & 0.306 & 0.174 & 1.710 & 0.091 \\
\hline Gender & 0.331 & 0.319 & 0.750 & 0.331 & 0.319 & 0.750 \\
\hline Retinopathy & 0.784 & 0.746 & 0.458 & 1.778 & 1.170 & 0.245 \\
\hline Overt nephropathy & -1.286 & -0.581 & 0.563 & -1.286 & -0.581 & 0.563 \\
\hline Microalbuminuria & -0.671 & -0.355 & 0.724 & -0.671 & -0.355 & -0.724 \\
\hline Peripheral artery disease & -0.549 & -0.246 & 0.806 & -2.182 & -0.665 & 0.508 \\
\hline
\end{tabular}

BBS: Berg Balance Scale; FES-I: Falls Efficacy Scale-International; HAblc: Hemoglobin (Hb) Alc.

\section{DISCUSSION}

The current study is the first comparing the balance and FOF in older patients with type $2 \mathrm{DM}$ and age- and gender-matched controls, along with evaluating the effects of diabetes and psychological status on balance and FOF in older diabetic patients. It is thus understandable that this study shows disturbed balance, increased FOF, reduced mobility and ambulation and increased disability in patients with DM compared to controls.

It is well known that with increasing age, FOF increases and balance is disturbed. ${ }^{[1,4,23]}$ since balance and FOF are closely associated parameters. The relationship between balance and FOF in older people has been reported in many studies. ${ }^{[13,23,24]}$ But little has been published on the relationship between balance and FOF in older patients with DM. Valpato et al. ${ }^{[5]}$ found that diabetes is associated with an increased risk of falling. High BMI and poor lower extremity performance are stronger predictors of fall in disabled older women with DM. In another study, it was reported that high BMI, educational level, use of walking aids, self-perceived physical health, and balance problems are associated with FOF in community-dwelling older people. ${ }^{[24]}$ However Kim et al. ${ }^{[25]}$ suggested there is no difference regarding FOF and number of falls between normal and overweight/obese patients. The same authors also showed that being more dependent and obese were related with balance disturbance. ${ }^{[25]}$ Although the study sample consisted of elderly people, in this study, balance parameters and FOF scores in patients with DM were worse than the control group. In the current study; DM patients compared to controls had higher BMI and they were more dependent in daily activities. High BMI and dependency in daily activities may have affected balance and FOF. Additionally, the number of falls of diabetic patients within the last year was more than the control group and this might be also a factor for increased FOF.

On the other hand, it has been reported that certain factors induced by diabetes itself have some negative effects on balance and falls..$^{[9,11]}$ Some authors defined DM and poor balance as independent risk factors for falling. ${ }^{[2,1]}$ Ageing with DM may add further deterioration of balance compared to those without DM. ${ }^{[1,7]}$ Several pathophysiological factors may mediate these differences, including decreased muscle strength, motor coordination and proprioception. ${ }^{[6,8,12]}$ Many DM related complications such as peripheral neuropathies, poor low contrast visual acuity and poor depth perception are also associated with reduced balance performance. ${ }^{[5,10,26]}$ Poor glycemic control, depressive symptoms and some medications may lead to poor balance; consequently increased probability of falls and enhanced FOF. ${ }^{[9,10]}$ However there is no detailed study evaluating the factors associated with diminished balance and 
increased FOF in DM. Therefore, the current study aims to identify factors affecting balance and FOF in older patients with DM.

In the current study, univariate analysis revealed that hypertension and cardiovascular disorders were the most important factors for FOF and balance in patients with DM. Cardiovascular disorders, peripheral neuropathy and obesity are risk factors for the deterioration of the physical disability in patient with $\mathrm{DM}^{.8,27]}$ In women suffering from DM, cardiovascular disease was found to be associated with disability and immobility. Some authors reported that hypertension and cardiovascular disease were more prevalent in older DM patients than in our study. ${ }^{[12,27]}$ In the same study, ${ }^{[12]}$ balance disturbance was present in all patients regardless of age. This can be explained by the hypothesis that hypertension and cardiovascular disease lead to immobility and inactivity, and they may be predisposing factors for FOF and balance disturbance as previously reported..$^{[8,11]}$

Additionally, the significant effect of neuropathic pain on FOF and balance was also found in patients with DM by univariate analysis, but peripheral neuropathy was not a factor on balance and FOF. Many studies suggest that peripheral neuropathy significantly influences FOF and balance ${ }^{[8,26,28]}$ On the contrary, Kelly et al. ${ }^{[29]}$ and IJzerman et al. ${ }^{[6]}$ demonstrated that FOF was prevalent in older adults with DM but it is unrelated to peripheral neuropathy. Lalli et al. ${ }^{[30]}$ demonstrated that the presence of neuropathic pain in patients with DM might impair gait and stability resulting in increased falls. The results of the current study can be explained by the low rate of peripheral neuropathy in our study. Since the effect of neuropathic pain on balance and FOF is not well known, this study may be guiding in this respect.

According to the results of our study, in DM patients BBS and FES-I were correlated with many clinical parameters except age. However, previous studies have shown that, age was an important factor for disturbed balance and FOF. ${ }^{[13,28]}$ The patients in the current study were between 61-80 years. In this age range, we have found that balance and FOF were not affected by age. If we had younger and older patients, we might have found that increasing age would be a factor disturbing the balance and increasing the FOF. In multiple regression analysis; the BBS of the DM patients was correlated with TUG, OLST and FES-I and this finding was consistent with other studies. ${ }^{[23,28]}$ On the other hand, FES-I was associated with HbAlc, MBI and BBS scores. This finding shows us that uncontrolled DM is a more permanent factor on the development of FOF than duration of the disease.

Fear of falling is also associated with sex and previously it was shown that the prevalence of FOF was consistently higher among women than men. ${ }^{[3]}$ It was suggested that being female and getting older are highly associated with FOF. ${ }^{[5,13,20]}$

Depression in DM contributes to poor metabolic control, decreased quality of life, and increased medical morbidity and mortality. ${ }^{[31,32]}$ Furthermore depression and other psychological factors may interfere with the functional mobility of older patients with DM. ${ }^{[31,32]}$ This study showed anxiety and depression test scores were significantly higher in patients compared to controls, as many investigators reported. ${ }^{[1,32]}$ Since BDI and BAI are related to BBS and FES-I, our study suggests that DM patients with anxiety and depression may be more likely to have balance disturbances and FOF. Kressig et al. ${ }^{[33]}$ showed depression may lead to an elevated risk of FOF. Therefore; longitudinal studies are warranted to elucidate the role of depression in the pathway from DM to poor balance and falls.

The main limitation of the study is the lack of evaluation of the mental status in patients with DM. The strength of the study is that it is very detailed and had strict exclusion criteria resulting in a homogeneous study. Another strength of the study is that all comorbid pathologies associated with DM were investigated. We also evaluated physiological status affecting the balance and FOF. The study included both women and men thus the results can be extrapolated to both genders. The inclusion of a healthy, age-matched control group of similar features added strength to the study.

In conclusion, in older patients with DM, FOF is increased and they have more balance disturbances compared to age matched individuals without DM. In the aspects of balance and FOF; gender, diabetes regulation, and comorbidities (especially cardiovascular disease and hypertension) and the presence of neuropathic pain have utmost importance in DM patients. Diabetes mellitus is a multi-systemic disease and multidisciplinary management is necessary. While comorbidities and complications of DM are evaluated by an endocrinologist; simultaneously, balance, mobility and functional capacities should be managed by a physiatrist. Older patients have problems induced by aging and DM. Such problems may have negative effects on balance and fear of falling. Strategies preventing falls and keeping balance and those against the fear of falling have utmost importance in these 
individuals. Furthermore, precautions for falls and FOF should include psychiatric evaluation.

\section{Declaration of conflicting interests}

The authors declared no conflicts of interest with respect to the authorship and/or publication of this article.

\section{Funding}

The authors received no financial support for the research and/or authorship of this article.

\section{REFERENCES}

1. Sturnieks DL, St George R, Lord SR. Balance disorders in the elderly. Neurophysiol Clin 2008;38:467-78.

2. Roman de Mettelinge T, Cambier D, Calders P, Van Den Noortgate N, Delbaere K. Understanding the relationship between type 2 diabetes mellitus and falls in older adults: a prospective cohort study. PLoS One 2013;8:67055.

3. Scheffer AC, Schuurmans MJ, van Dijk N, van der Hooft T, de Rooij SE. Fear of falling: measurement strategy, prevalence, risk factors and consequences among older persons. Age Ageing 2008;37:19-24.

4. Painter JA, Allison L, Dhingra P, Daughtery J, Cogdill K, Trujillo LG. Fear of falling and its relationship with anxiety, depression, and activity engagement among community-dwelling older adults. Am J Occup Ther 2012;66:169-76.

5. Volpato S, Leveille SG, Blaum C, Fried LP, Guralnik JM. Risk factors for falls in older disabled women with diabetes: the women's health and aging study. J Gerontol A Biol Sci Med Sci 2005;60:1539-45.

6. IJzerman TH, Schaper NC, Melai T, Meijer K, Willems PJ, Savelberg HH. Lower extremity muscle strength is reduced in people with type 2 diabetes, with and without polyneuropathy, and is associated with impaired mobility and reduced quality of life. Diabetes Res Clin Pract 2012;95:345-51.

7. Morrison S, Colberg SR, Mariano M, Parson HK, Vinik AI. Balance training reduces falls risk in older individuals with type 2 diabetes. Diabetes Care 2010;33:748-50.

8. Schwartz AV, Hillier TA, Sellmeyer DE, Resnick HE, Gregg E, Ensrud KE, et al. Older women with diabetes have a higher risk of falls: a prospective study. Diabetes Care 2002;25:1749-54.

9. Tilling LM, Darawil K, Britton M. Falls as a complication of diabetes mellitus in older people. J Diabetes Complications 2006;20:158-62.

10. Macgilchrist C, Paul L, Ellis BM, Howe TE, Kennon B, Godwin J. Lower-limb risk factors for falls in people with diabetes mellitus. Diabet Med 2010;27:162-8.

11. Maurer MS, Burcham J, Cheng H. Diabetes mellitus is associated with an increased risk of falls in elderly residents of a long-term care facility. J Gerontol A Biol Sci Med Sci 2005;60:1157-62.

12. Petrofsky JS, Focil N, Prowse M, Kim Y, Berk L, Bains G, et al. Autonomic stress and balance--the impact of age and diabetes. Diabetes Technol Ther 2010;12:475-81.
13. Bruce D, Hunter M, Peters K, Davis T, Davis W. Fear of falling is common in patients with type 2 diabetes and is associated with increased risk of falls. Age Ageing 2015;44:687-90.

14. American Diabetes Association. Standards of medical care in diabetes--2014. Diabetes Care 2014;37:14-80.

15. Yucel A, Senocak M, Kocasoy Orhan E, Cimen A, Ertas M. Results of the Leeds assessment of neuropathic symptoms and signs pain scale in Turkey: a validation study. J Pain 2004;5:427-32.

16. Ekvall Hansson E, Månsson NO, Ringsberg KA, Håkansson A. Dizziness among patients with whiplash-associated disorder: a randomized controlled trial. J Rehabil Med 2006;38:387-90.

17. Sahin F, Yilmaz F, Ozmaden A, Kotevolu N, Sahin T, Kuran B. Reliability and validity of the Turkish version of the Berg Balance Scale. J Geriatr Phys Ther 2008;31:32-7.

18. Greene BR, O'Donovan A, Romero-Ortuno R, Cogan L, Scanaill CN, Kenny RA. Quantitative falls risk assessment using the timed up and go test. IEEE Trans Biomed Eng 2010;57:2918-26.

19. Küçükdeveci AA, Yavuzer G, Tennant A, Süldür N, Sonel B, Arasil T. Adaptation of the modified Barthel Index for use in physical medicine and rehabilitation in Turkey. Scand J Rehabil Med 2000;32:87-92.

20. Ulus Y, Durmus D, Akyol Y, Terzi Y, Bilgici A, Kuru O. Reliability and validity of the Turkish version of the Falls Efficacy Scale International (FES-I) in community-dwelling older persons. Arch Gerontol Geriatr 2012;54:429-33.

21. Hisli N. Beck depresyon envanterinin geçerliliği üzerine bir çalışma. Psikoloji Dergisi 1988;22:118-26.

22. Ulusoy M, Şahin N, Erkmen H. Turkish version of the Beck Anxiety Inventory. J Cognitive Psychother 1998;12:163-72.

23. Ersoy Y, MacWalter RS, Durmus B, Altay ZE, Baysal O. Predictive effects of different clinical balance measures and the fear of falling on falls in postmenopausal women aged 50 years and over. Gerontology 2009;55:660-5.

24. Kumar A, Carpenter H, Morris R, Iliffe S, Kendrick D. Which factors are associated with fear of falling in communitydwelling older people? Age Ageing 2014;43:76-84.

25. Kim H, Suzuki T, Yoshida H, Yoshida Y, Shimada H. Prevalence of geriatric syndrome and risk factors associated with obesity in community-dwelling elderly women. Nihon Ronen Igakkai Zasshi 2008;45:414-20. [Abstract]

26. Ghanavati T, Shaterzadeh Yazdi MJ, Goharpey S, Arastoo AA. Functional balance in elderly with diabetic neuropathy. Diabetes Res Clin Pract 2012;96:24-8.

27. Maty SC, Fried LP, Volpato S, Williamson J, Brancati FL, Blaum CS. Patterns of disability related to diabetes mellitus in older women. J Gerontol A Biol Sci Med Sci 2004;59:148-53.

28. Pijpers E, Ferreira I, de Jongh RT, Deeg DJ, Lips P, Stehouwer $\mathrm{CD}$, et al. Older individuals with diabetes have an increased risk of recurrent falls: analysis of potential mediating factors: the Longitudinal Ageing Study Amsterdam. Age Ageing 2012;41:358-65.

29. Kelly C, Fleischer A, Yalla S, Grewal GS, Albright R, Berns $\mathrm{D}$, et al. Fear of falling is prevalent in older adults with diabetes mellitus but is unrelated to level of neuropathy. J Am Podiatr Med Assoc 2013;103:480-8. 
30. Lalli P, Chan A, Garven A, Midha N, Chan C, Brady $S$, et al. Increased gait variability in diabetes mellitus patients with neuropathic pain. J Diabetes Complications 2013;27:248-54.

31. Talbot F, Nouwen A. A review of the relationship between depression and diabetes in adults: is there a link? Diabetes Care 2000;23:1556-62.
32. Egede LE. Diabetes, major depression, and functional disability among U.S. adults. Diabetes Care 2004;27:421-8.

33. Kressig RW, Wolf SL, Sattin RW, O'Grady M, Greenspan A, Curns A, et al. Associations of demographic, functional, and behavioral characteristics with activity-related fear of falling among older adults transitioning to frailty. J Am Geriatr Soc 2001;49:1456-62. 